\title{
MULLEROCHLOA, A NEW GENUS OF BAMBOO (POACEAE: BAMBUSOIDEAE) FROM NORTH-EAST AUSTRALIA AND NOTES ON THE CIRCUMSCRIPTION OF BAMBUSA
}

\author{
K.M. WONG \\ Institute of Biological Sciences, University of Malaya, 50603 Kuala Lumpur, Malaysia \\ e-mail: wong@um.edu.my
}

\section{SUMMARY}

\begin{abstract}
A climbing bamboo endemic to North Queensland in Australia, previously named Bambusa moreheadiana, represents a new monotypic endemic genus there, Mullerochloa. Its clambering-scrambling, generally non-twining habit, sympodial rhizomes, inflated proximal ends of culm internodes and culm sheaths with a wrinkled basal zone, are distinctive vegetative characters. Additional important characters of the reproductive system include the iterauctant flowering habit, producing clusters of pseudospikelets, each with 4-9 flowers and a terminal vestigial flower; paleas that conspicuously exceed the lemmas in length; consistently four anthers borne on a filament tube; and a glabrous ovary. A discussion of the circumscription of the Asiatic genus Bambusa, with which a number of other distinct genera, including Mullerochloa, have been confused, is provided.
\end{abstract}

Key words: Bambusoideae, Poaceae, Bambusa, Mullerochloa, North Queensland, climbing bamboo.

\section{INTRODUCTION}

Three species of woody bamboo have been documented as indigenous to Australia. One is an erect, spiny bamboo called Bambusa arnhemica F. Muell., endemic to the monsoonal northernmost parts of the Northern Territory (Franklin, 2003a). The other two species of woody bamboo grow in rain forest in the northern Queensland region and develop slender, clambering or leaning culms: both these species were also originally classified as species of Bambusa Schreb., B. forbesii (Ridl.) Holttum and B. moreheadiana F.M. Bailey.

In its habit, most of its vegetative structure and reproductive parts, $B$. arnhemica has much similarity to the typical species of Bambusa in mainland Asia, including the type species B. bambos (L.) Voss, and thus seems appropriately placed in that genus. The other two clambering-scrambling bamboos have been placed within Bambusa only with much uncertainty. Whereas $B$. forbesii is now considered a synonym of Neololeba atra (Lindl.) Widjaja (Widjaja, 1997), B. moreheadiana (Fig. 1-4) has continued to be accepted in Bambusa only in a broad circumscription of the latter (Clifford, 1993). Basically, this general circumscription followed that by Holttum $(1946,1958)$, whose work became a foundation for modern systematic studies into Old World bamboos, where generic recognition became better associated with characters of spikelet (or pseudospikelet) and flower structure. 


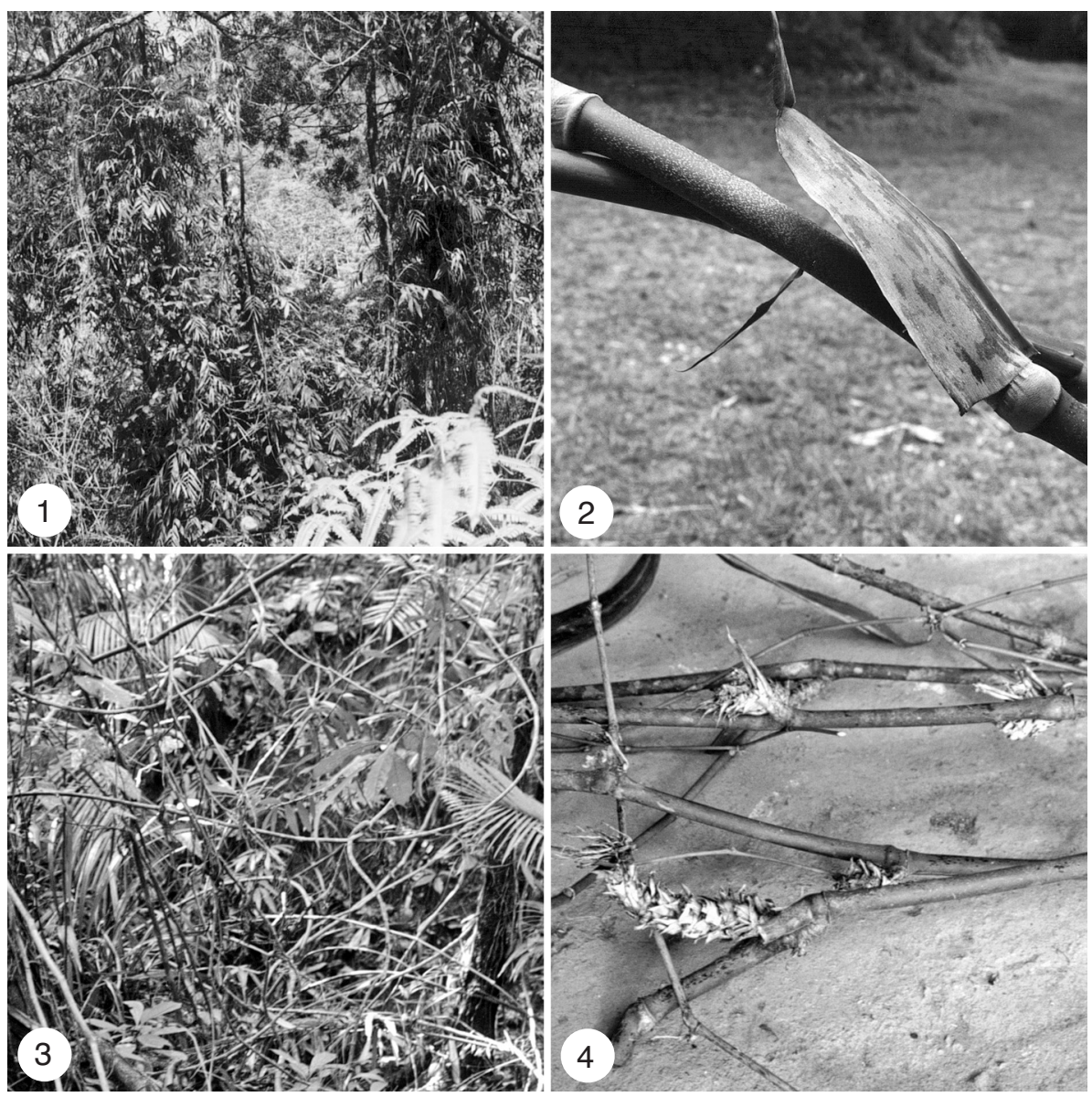

Fig. 1-4. - 1. Climbing-scrambling habit of Mullerochloa moreheadiana (F.M. Bailey) K.M. Wong (formerly called Bambusa moreheadiana F.M. Bailey) in the forest at Mount Mirinjo Farm, Northern Queensland. - 2. Mature Mullerochloa moreheadiana culm sheath detaching from its thickened, finely wrinkled basal part. - 3. Scrambling, entangled culms of Mullerochloa moreheadiana in the forest at Mt Mirinjo Farm. - 4. Some examples of recumbent culms, showing a number of culm branch buds developing rhizome-like extensions with short internodes, overlapping chaffy sheaths and roots (all photos: Len Muller).

In distinguishing among related genera, Holttum considered that Bambusa spp. have in common such characters as the presence of a terminal vestigial flower and long rachilla internodes that disarticulate below the lemmae in the spikelet, and the presence of three lodicules and a keeled palea with an acuminate or truncate apex in each flower. Moreover, B. moreheadiana has (4-)5-9 flowers, and so has resemblance to the better known mainland Asiatic species of Bambusa, including the type species, B. bambos, which typically have more than just one or two flowers in the pseudospikelet. The individual lemmas in the $B$. moreheadiana pseudospikelet are also slightly divergent from the rachilla axis of the spikelet, again resembling the condition in several Asiatic Bambusa species. 
Clambering-scrambling or climbing culm habits are not unfamiliar to those who know Southeast Asian bamboos, of which Dinochloa Buse, for example, is a well-known twining forest bamboo (Dransfield, 1981, 1996; Wong, 1986). Also, an heterogeneous assemblage of clambering-scrambling taxa once placed in Bambusa have now been recognized as distinct genera, viz., Sphaerobambos S. Dransf. from Borneo, the Philippines and Sulawesi (Dransfield, 1989); Holttumochloa K.M. Wong, Maclurochloa K.M. Wong and Soejatmia K.M. Wong from the Malay Peninsula, Kinabaluchloa K.M. Wong from the Malay Peninsula and Borneo (Wong, 1993a, 1995b); Fimbribambusa Widjaja from East Java and New Guinea, and Neololeba Widjaja from the Philippines and central and eastern Indonesian islands, New Guinea and Queensland (Widjaja, 1997). Some Philippine species with scrambling culms once placed in Schizostachyum Nees have been diagnosed as a distinct genus, Cyrtochloa S. Dransf. (Dransfield, 1998), although there are species of Schizostachyum that indeed have a scrambling habit, such as S. terminale Holttum from the Malay Peninsula and Borneo (Wong, 1991). Still other scrambling taxa exist, such as Racemobambos Holttum (Wong, 1981; Dransfield, 1983), most species now placed in Nastus Nees (Holttum, 1967; Soenarko, 1977; Widjaja, 1997) and Temburongia S. Dransf. \& K. M. Wong (Dransfield \& Wong, 1996). The last three genera mentioned all have determinate inflorescences, the spikelets developing individually and are unable to branch due to a lack of basal buds, thus not forming clusters or tufts of similar units of progressively higher branching order, which are known as pseudospikelets, such as in those genera earlier mentioned (McClure, 1934, 1966).

\section{AN IMPROVING CIRCUMSCRIPTION OF BAMBUSA}

Nevertheless, the inclusion within Bambusa s.l. of a number of species that were widely different in the number of flowers in the pseudospikelet, and which had very different growth habits ranging from big erect bamboos to slender scrambling forms, as well as very diverse characters for branching and culm sheaths, called into question the validity of this earlier characterization of Bambusa. Investigating essentially these aspects for taxa previously classified in Bambusa in Malaysia, Wong (1993a, b, 1995a) found many additional characters for distinguishing a number of genera from among such species, which could be clearly demarcated from the type alliance of Bambusa s.s. Thus, for example, Holttumochloa differed in having multiple branch buds at a culm node instead of a solitary bud and the individual branches were all similarly slender and seldom re-branched (true for all three species known); Kinabaluchloa differed in having each developing pseudospikelet subtended by a large bract equalling the lemma in length, a slender cylindric ovary and a mid-culm branch complement without a clear dominant element (these characters present in both species known); Maclurochloa differed in the large number of empty glumes below the flowers and an ovary summit that is not thickened; and Soejatmia had rudimentary flowers below the perfect flowers and a distinctly bifid palea apex with hooked tips.

There were still other points of difference between these genera and Bambusa s.s., but it was clear that among species of the Bambusa-type alliance the inter-species differences were not of this nature, being, instead, in such characters as the colour of the anthers, fused or free filaments, number of stigmas, length of style, and hairiness 
and size of pseudospikelet parts. Similarly, Widjaja (1997) was able to distinguish Fimbribambusa by its patellate culm nodes (Bambusa culm nodes do not develop any patella or narrow shelf skirting the culm) and non-thickened ovary apex (Bambusa and close allies have ovaries with a thickened apex); and Neololeba by its lack of lodicules in the flower (Bambusa spp. consistently have 3 lodicules) and lack of a terminal vestigial flower (Bambusa typically has 1-3 terminal vestigial flowers in its pseudospikelet), among other characters. These characters are true for both species of Fimbribambusa known and four of five known species of Neololeba documented with flowering material. Limited comparisons (Muller, 1997; Liese, 1998) also showed that the arrangement of sclerenchyma and vascular bundles in transverse sections of the culm of Neololeba atra (as Bambusa forbesii) was very different from that typical of Bambusa and its allies.

Therefore, when these aberrant taxa are removed from Bambusa as circumscribed according to its type alliance of species, clearly demarcated groups can be recognized, with their essential differences being found especially in pseudospikelet structure (including the number of perfect flowers and presence of terminal vestigial flowers), the form of the palea, ovary structure and hairiness, and the presence of lodicules. In vegetative characters, the groups newly demarcated from Bambusa s.s. variously show important distinguishing characters in culm habit (Bambusa spp. are erect to suberect, not scrambling or climbing), architectural attributes such as the structure of the midculm branch complement (typical Bambusa have a branch complement developing from a single bud with a clearly dominant primary axis), and certain characters of the culm sheath (typical Bambusa do not have reflexed, linear blades and a wrinkled zone at the base of the sheath, for example) and node (development of a patella or a ring of patent bristles, for example).

There is no doubt that, as we are able to make more collections and morphological studies that improve our understanding of structure and details, especially of the pseudospikelets, flowers and fruits, and make better observations of plant architecture and habit, defining characters for groups (e.g., genera) will become more evident. We are nearer to the point when cladistic approaches will be more rewarding, remembering that, of course, when superficial characters are utilised in an analysis, superficial groups will form. A more resolute picture using DNA characters will be provided if the sampling is carried out against a clearer hypothesis presented by better group definitions, rather than a rudimentary classification based on very little. This is especially so for bamboos, given the paucity of collections in the past and the dearth of detailed studies, often with only superficial characters recorded in the older works.

In summary, an emerging improved definition of Bambusa around a core of mainland Asiatic species clearly allied to the type, B. bambos, is represented by the following character states (Wong, 1993b): Rhizomes sympodial; culms erect-suberect and not scrambling or climbing, culm internodes without sudden distension at the basalmost zone (general large distensions of the internode sometimes present in teratological forms); culm sheaths without any wrinkled zone at the base, with blades erect (at least initially) and auricles typically lobe-like and bristly on the margin (but exceptionally small and inconspicuous or not developed); buds at culm nodes solitary; mid-culm branch complement with a dominant primary branch and 1-several secondary branches and usually several smaller branchlets from its base, basal branches developing short, in- 
durated axillary spine-branches in a number of species; leafy branches further branching as they develop inflorescences; inflorescences iterauctant (producing pseudospikelets as the basic unit); pseudospikelets typically longer than $1 \mathrm{~cm}$, often several $\mathrm{cm}$ long, consisting of 0 -several small empty bracts, 1 -several bracts subtending prophyllate buds, 0 -several transitional (empty) glumes that are shorter than the lowest lemma, 3-10 perfect flowers and 1-3 terminal vestigial flowers; rachilla internodes between flowers elongated, slightly flattened, disarticulating below the lemmas; palea shorter or as long as lemma (not conspicuously exceeding it), with 2 hairy keels, glabrous or shorthairy at the upper half on the inside between the keels, apex acuminate to rounded or slightly cleft but not distinctly bifid; lodicules 3 with hairy margins; stamens 6 , filaments free or (rarely) fused; ovary obovoid with thickened and hairy summit; stigmas 1-3 arising directly from the ovary summit or on a long hairy style; fruit obovoid-cylindric with thickened and hairy summit.

The confusion of distinct genera with the essentially Asiatic Bambusa has been the most severe in the Far East but this situation is now much clarified with clear definitions of a suite of such genera that are special to the region, in particular the Malay Archipelago and Australasian area. The erect Bambusa arnhemica conforms to this character syndrome of Bambusa, but the other two Australian bamboos, Neololeba atra and the species known as $B$. moreheadiana, do not. Here, $B$. moreheadiana is compared with Bambusa and other taxa and transferred to a new genus, Mullerochloa K.M. Wong.

\section{DISTINGUISHING THE NEW GENUS}

Table 1 provides a comparison of habit and vegetative characters, and Table 2 of pseudospikelet and flower characters, among the new Queensland genus (Mullerochloa) and Bambusa s.s., as well as other climbing-scrambling genera that have a characteristic wrinkled zone at the very basal part of the culm sheath, such as in Dinochloa. These genera were selected because the species representing Mullerochloa has been confused with Bambusa in the past, and also has slender culms with a climbing-scrambling habit, with culm sheaths that have a conspicuous wrinkled zone at the very base (Fig. 2, 5).

Mullerochloa has many clear differences from Bambusa. Its climbing habit is quite alien to Bambusa as defined above. The culm sheaths with a wrinkled basal zone are also not known in Bambusa s.s., where the sheath base is never rugose in this way. The culm sheath blades of Mullerochloa are patent to reflexed (Fig. 2, 5), another difference from Bambusa sheaths where blades are typically erect, at least at first. Besides the vegetative characters surveyed in Table 1, additional features that support the distinction of Mullerochloa from Bambusa s.s. is found in anatomical characteristics of the middle culm portion. Transverse sections of bamboo mid-culm portions reveal vascular bundles (strands) that are scattered throughout the ground tissue. Variation among different bamboos, especially genera and groups of genera, is found in such features as: a) the relative sizes of the sclerenchyma (fibre) sheaths adjacent to the phloem, the two metaxylem vessels and the protoxylem space (which together form a discrete vascular bundle and its accompanying fibre sheaths); b) the occurrence of one or more additional sclerenchyma bundles on the inner side of (and separate from) the vascular bundle; c) the occurrence of another sclerenchyma bundle on the outer side of (and separate from) the vascular bundle; and d) the occurrence of other (usually smaller) 


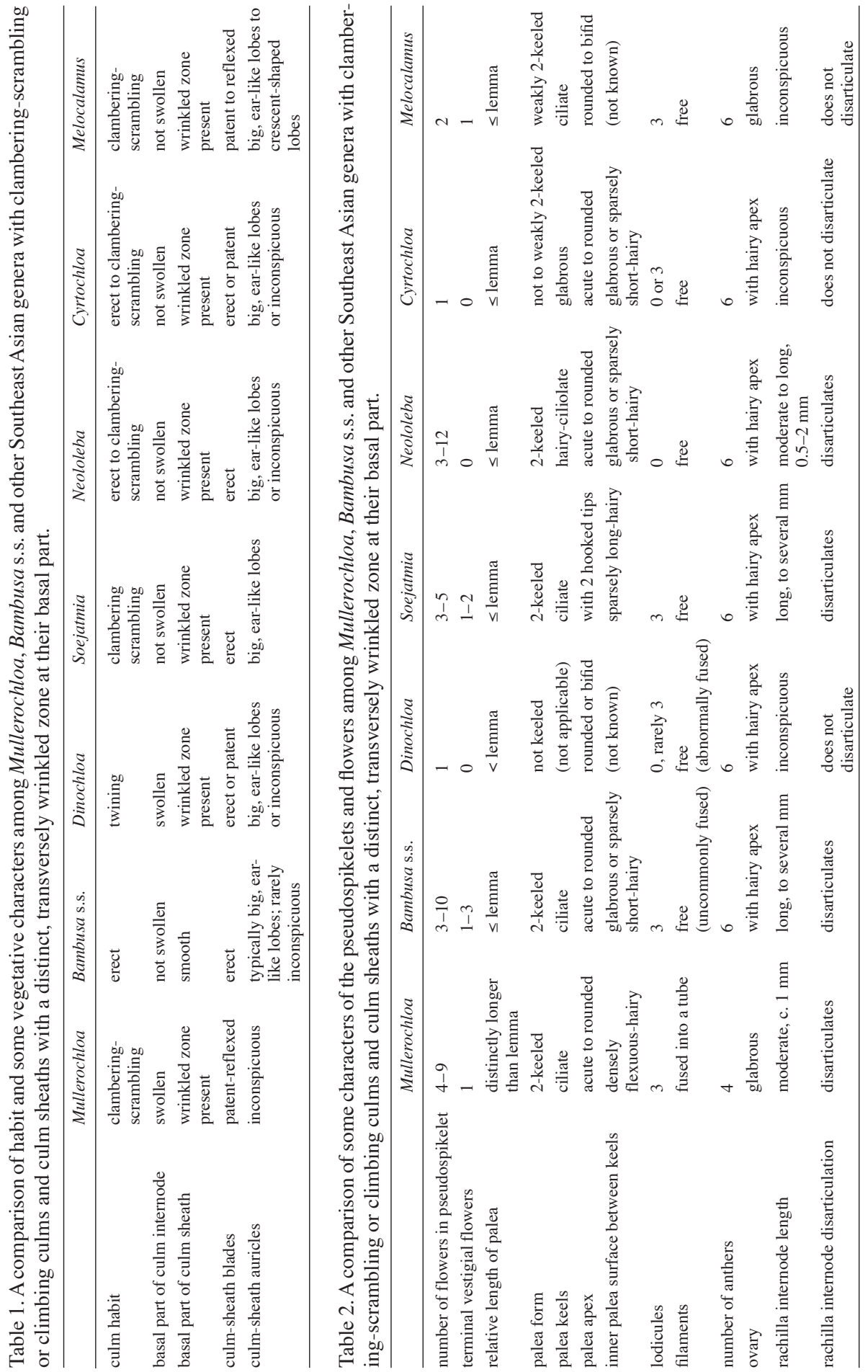




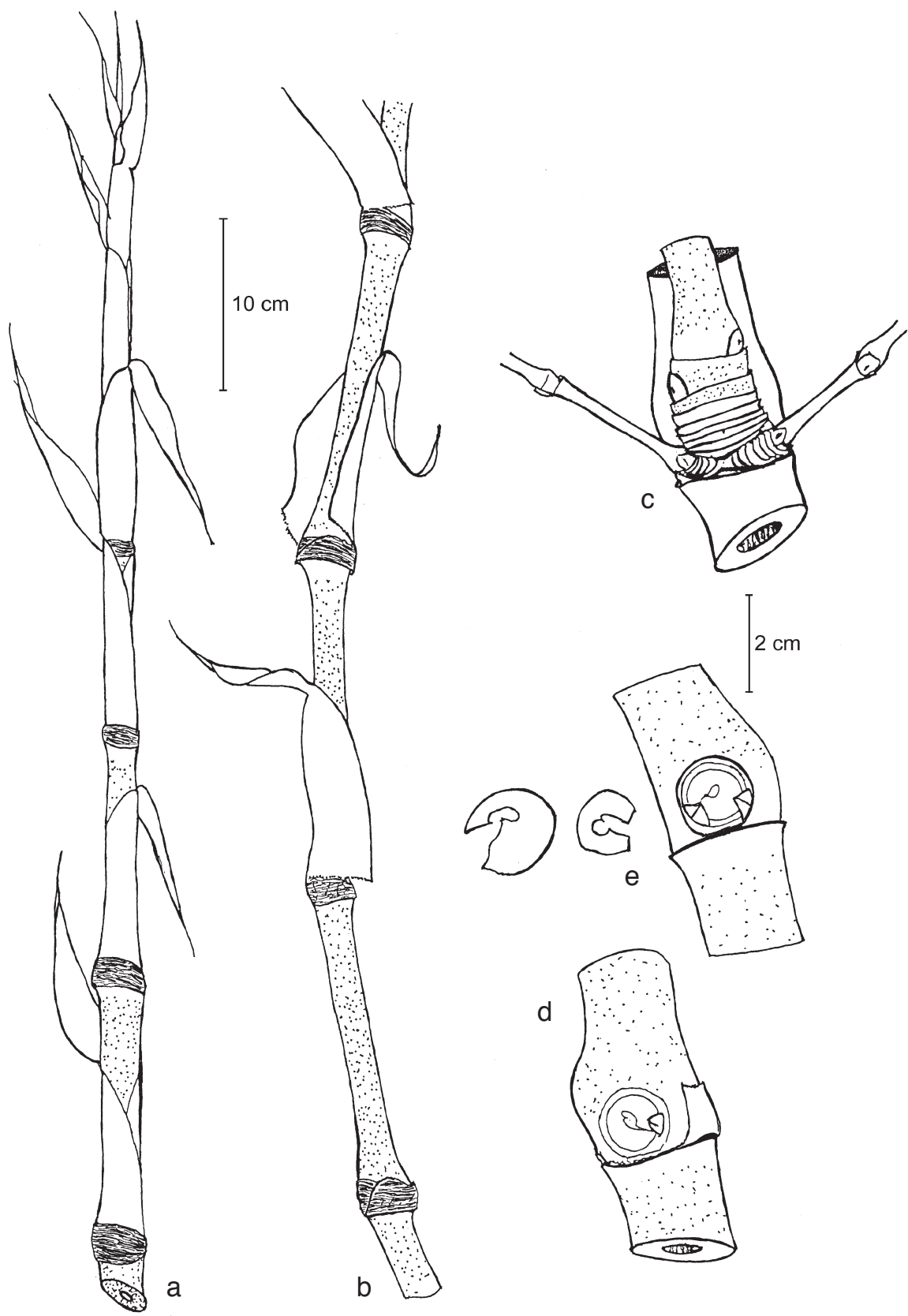

Fig. 5. Some vegetative parts of Mullerochloa moreheadiana (F.M. Bailey) K. M. Wong. - a. Fresh culm shoot showing each node ensheathed by a distinct, finely wrinkled and thickened basal portion of the culm sheath, and patent culm-sheath blades; $b$. older culm shoot, the culm sheaths beginning to detach from their thickened bases; c. branch complement; d \& e. primary branch bud at a culm node, with prophyll and first sheath removed, respectively, showing secondary branch buds (drawing by Len Muller based on Muller s.n. (KLU)). 

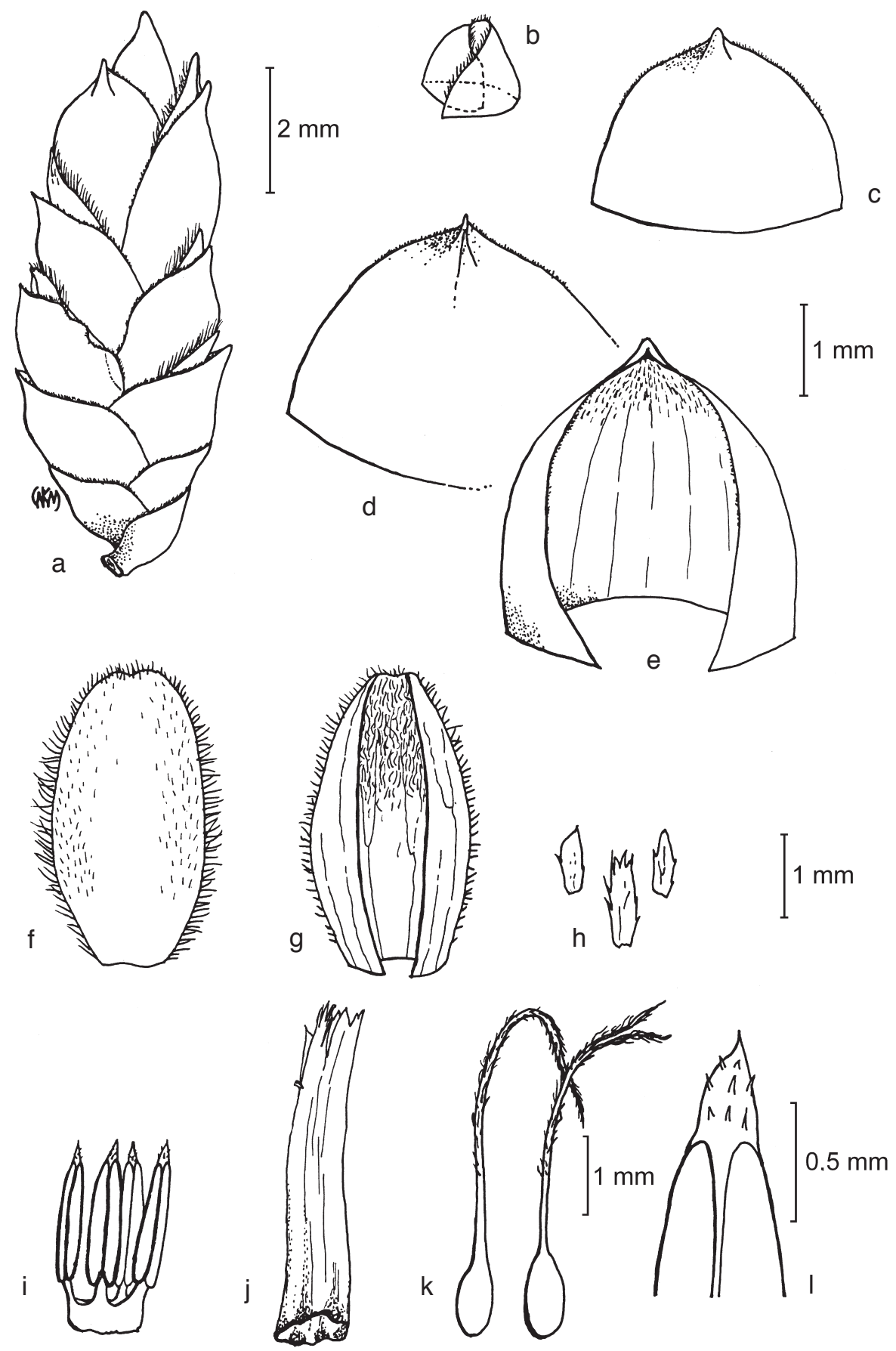
fibre bundles scattered between the main vascular bundles (Liese \& Grosser, 2000; Wong, 1995a). In species belonging to the typical alliance of Bambusa, the vascular bundle in cross-sectional view typically has thick fibre sheaths accompanying the phloem, metaxylem vessels and protoxylem area, and there is an additional, separate sclerenchyma bundle on the inner side to the vascular bundle. This is Type III in the typology of Liese \& Grosser (2000); there are one or two variations of this, denoted as other 'types', but in mid-culm positions, Type III is the consistently present major type found. In $B$. moreheadiana, the vascular bundle has only very thin sclerenchyma sheaths accompanying the phloem, metaxylem vessels and protoxylem area, and additional, separate sclerenchyma bundles are typically absent. This falls into Type VIa of Liese \& Grosser (2000).

In Mullerochloa pseudospikelets, the rachilla internodes are conspicuous, but they are strongly flattened and measure almost as long as the rachilla internode width, and so are not truly elongate in the same way as typical Bambusa rachilla internodes, which are only slightly compressed, the lengths always exceeding the thickness of the rachilla. The palea in Mullerochloa is conspicuously longer than the lemma, so that the paleas protrude visibly in the mature pseudospikelet (Fig. 6), as also figured by Clifford (1993); this character is comparatively rare among bamboos and is not found among true Bambusa spp., where the paleas are shorter than or at most equal to the lemmas in length. Among Southeast Asian bamboos, Sphaerobambos (one of the species previously placed in Bambusa) also has the paleas exceeding the lemmas in length (Dransfield, 1989); but in that genus, all paleas develop a narrow wing along their keels, whereas Mullerochloa has palea keels without such wings. Also, the paleas in Bambusa spp. are generally glabrous or at most scattered short-hairy over the upper half of the inner surface between the keels, whereas in Mullerochloa the paleas are densely flexuous-hairy on the inner side between the keels. Soejatmia also has paleas that are hairy on the general inside surface between the keels, but other characters, such as the shorter paleas (hidden by the lemmas in the pseudospikelet) and presence of two hooked projections at the palea apex, distinguish that from Mullerochloa. The ovary in Mullerochloa is narrowly ovoid to cylindric and glabrous, whereas in Bambusa it is typically broad-obovoid with a thickened hairy apex (Table 2).

The superficial resemblance of Mullerochloa to Dinochloa is found in the presence of an abrupt swelling or distension of the very basal part of the culm internodes and in the wrinkled zone at the very base of the culm sheaths in both genera. This swelling appears correlated to the ability of each developing internode to grow in a different

Fig. 6. Pseudospikelet and flower parts of Mullerochloa moreheadiana (F.M. Bailey) K.M. Wong. - a. Pseudospikelet with two bracts subtending prophyllated buds (not visible) at the very base, followed by two empty glumes and, more distally, seven flowers, terminated by a vestigial flower (hidden at the apex); b. prophyll subtending a new pseudospikelet branch; c. empty glume; d. lemma, dorsal aspect; e. lemma, ventral view with short hairs on the inner surface; f. palea, dorsal or back view, with ciliate keels; g. palea, ventral aspect with short flexuous hairs on the inner surface and two glabrous wings; h. lodicule complement; i. complement of four stamens from a young flower, joined by a short staminal tube; j. remains of staminal tube from an old flower from which the anthers have dropped; k. two ovaries, one with a simple stigma, the other with a bifid stigma; 1. detail of anther apex, showing spinulose connective (drawing by K.M. Wong based on Kerns s.n. (K)). 
direction from that of the previous internode, so that the growing culm can more effectively extend around obstacles, and so contribute to a successful climbing habit (Wong, 1986). As a result, culms bent at nearly right angles at the nodes are possible. However, the resemblance ends there. Whereas Dinochloa culms twine around tree stems and branches (Wong, 1995a, b; Dransfield, 1981), those of Mullerochloa generally have a clambering or scrambling habit (Fig. 3), attaching to nearby plants by their entangled branches. Occasionally, Mullerochloa culms or branches form a loose, poorly defined spiral as they twist around each other, but this is not a consistent culm habit as in Dinochloa, where the twining is a definite, clearly spiral-forming culm development around trunks and branches of trees. Dinochloa spp. have only one flower in the pseudospikelet, inconspicuous rachilla internodes and lacks a terminal vestigial flower, whereas Mullerochloa has as many as 4-9 flowers per pseudospikelet, conspicuous rachilla internodes, with a terminal vestigial flower present. The palea in Dinochloa is not keeled, that in Mullerochloa is distinctly 2-keeled. Dinochloa has no lodicules and free filaments in the flower, Mullerochloa has three lodicules and the filaments are fused into a tube. The ovary summit in Dinochloa is thickened and hairy, that in Mullerochloa is not thickened and glabrous. The two genera are, therefore, significantly different.

Table 1 and 2 also compare characters in Mullerochloa with Soejatmia, Neololeba, Cyrtochloa and Melocalamus Benth., the other clambering or climbing bamboos found within the general Southeast Asian region. Among the features that distinguish these genera from Mullerochloa are: 1) the terete culms without any swellings at the base of the internode, paleas that do not exceed the lemmas in length, and six stamens with free filaments in all four of these genera (Mullerochloa has culm internodes with conspicuous basal swellings, paleas that are distinctly longer than the lemmas, and consistently four stamens with the filaments fused into a delicate tube);2) the obovoid ovary with hairy apex in Soejatmia, Neololeba and Cyrtochloa (Mullerochloa has a slender ovoid to cylindric ovary that is glabrous); 3 ) the presence of only one or two flowers in the pseudospikelet and inconspicuous rachilla internodes that do not disarticulate below the lemma in Cyrtochloa and Melocalamus (Mullerochloa has 4-9 flowers with conspicuous rachilla internodes that disarticulate below the lemma); 4) the lack of a terminal vestigial flower in the pseudospikelets of Neololeba and Cyrtochloa (Mullerochloa has a terminal vestigial flower); and 5) the glabrous and weakly developed palea keels of Cyrtochloa (Mullerochloa has bristly, distinct palea keels).

\section{DESCRIPTION OF THE NEW GENUS}

Mullerochloa K.M. Wong, nov. gen.

Genus Graminearum-Bambusoidearum novum rhizomatis sympodialibus, culmis ascendentibus, internodiis basis distento; vaginis culmi basin rugosis; inflorescentiis iterauctantibus; structura spiculae distincta, pseudospicula 1-2 glumas, internodio rachillae intermedio ca. $1 \mathrm{~mm}$ longo, flosculo imperfecto unico; flosculo hermaphrodito 4-9, palea bicarinata et intus inter carinas pubescenti, lemmatibus longior, 3 lodiculis, 4 staminibus filamentis conjunctis, ovario cylindraceo gracile glabro. - Typus: Mullerochloa moreheadiana (F.M. Bailey) K.M. Wong.

Rhizome system sympodial. Culms clambering or climbing, internodes basally distended; culm sheath with a rugose basal zone with irregular transverse wrinkles. Inflorescence iterauctant; pseudospikelet with 1 or 2 empty glumes, rachilla internodes 
c. $1 \mathrm{~mm}$ long and a terminal vestigial flower. Hermaphrodite flowers 4-9, with 2-keeled palea hairy on the inside between the keels and longer than the lemma, 3 lodicules, 4 stamens with fused filaments, and a glabrous, narrowly cylindric ovary.

The genus as known is monotypic and endemic to the North Queensland region of Australia. Its sole species, $M$. moreheadiana occurs from just south of Cooktown to about $20 \mathrm{~km}$ south of Innisfail, an area of about 300 by $20 \mathrm{~km}$ (L. Muller, pers. comm.). It is a climber in rain forest of the coastal plain there. It is more plentiful in wet areas near the Daintree River, Russell River, and on the heavily forested areas of the Bellenden-Ker Range and foothills to the south. All of the area of distribution receives annual rainfall of 3000-4000 $\mathrm{mm}$ and the soils are mainly acid red soil of basaltic origin, with some sandy loam in areas of run-off from the hills. It does not occur within the drier parts of the coastal ranges, or in any of the dry sclerophyll forest of the coastal plain.

Notwithstanding a clearer emerging picture of general plant biogeography (Morley, 2003), the relationships of Mullerochloa and other Australian bamboos are still contentious. From habit and morphology alone, the affinities of Mullerochloa would appear to be with other clambering or climbing bamboos, in particular those with a wrinkled basal part in the culm sheath, spikelets with many flowers, disarticulating rachilla internodes and 2-keeled paleas, such as Soejatmia and Neololeba (Table 1 $\& 2$ ). These are Malesian and Australasian taxa more-or-less restricted to the region from South Asia to North-East Australia. As taxonomic development of bamboos is diverse in South America and the area from India to South and East Asia and the Malesian-Australasian region, and apparently very poor in Africa and none in Europe, woody bamboos appear to be an essentially Gondwanan group that had successfully proliferated in South America and the south and east Asian regions, the latter possibly through colonization or enrichment via the rafting of the Indian plate towards collision with Asia. Yet, residual bamboos on the Australian plate cannot yet be ruled out, as relict or ancient genera and families of flowering plants are known to have persisted in the remaining rain forest fragments there as the continent became increasingly dry (Bowman et al., 1988; Morley, 2003). The presence of the endemic B. arnhemica in northern Australia, sole representative there of a genus otherwise welldeveloped only in South and East Asia, may suggest that Bambusa colonized Australia from Asia. Mullerochloa and Neololeba, the other two Australian genera that are closely related to one another but highly distinct from Bambusa, may represent another one or two colonization events; Franklin (2003b) supposes the three endemic bamboos there represent at least three colonization events.

Mullerochloa is named after Mr Lennox Muller of Innisfail, Queensland, whose keen interest in bamboos has been a source of inspiration and who has long doubted the affinity of the species here to Bambusa.

\section{Mullerochloa moreheadiana (F.M. Bailey) K.M. Wong, comb. nov.}

Bambusa moreheadiana F.M. Bailey (1889) 26; Clifford (1993) 131. - Type: F.M. Bailey s.n., July/ August 1888, Queensland, Cook District, Russell River, Harvey's Creek (holo BRI; iso K).

Climbing bamboo, to $30 \mathrm{~m}$ high on trees, rhizome system basically sympodial but new rhizomes sometimes developing from culm buds along lengths of culm on or near to the forest floor or in very moist sites. Culms loosely caespitose in developing clumps, 
mostly scrambling to clambering (non-twining) on and entangling with surrounding vegetation, or occasionally weakly twisting around itself and other small support or branches, often draping over the forest floor; internodes $12-30 \mathrm{~cm}$ long, $0.5-4.5 \mathrm{~cm}$ in diameter, basal ones frequently solid, more distal ones generally thick-walled, medium green, with scattered short appressed pale silvery hairs all over, later glabrescent, non-waxy, the very basal portion conspicuously swollen. Culm sheath with pale hairs sparsely all over the back, more towards the base, purplish brown to greenish brown, the very basal part with a distinct light-green leathery zone with irregular transverse wrinkles, more conspicuous when dry; blade narrowly lanceolate, to $8-10 \mathrm{~cm}$ long, $1-2 \mathrm{~cm}$ wide, abaxially purple, adaxially paler and lightly white-waxy, hairs completely absent, patent to somewhat reflexed; auricles indistinct, glabrous; ligule a low rim 1-2 mm high, subentire, without bristles. Mid-culm branch complement developing from a single bud (the prophyll subtending this bud 2-keeled, the keels short-ciliate), comprising a dominant primary axis alone or with 1 or 2 subdominant secondary axes and several higher-order axes near its base, the dominant able to reiterate the growth of the culm, becoming quite long itself and tangling with surrounding plants. Leaf sheaths about $10 \mathrm{~cm}$ long with scattered short, pale hairs; auricles represented by an indistinct ridge or absent, glabrous; ligule a short and membranous inconspicuous rim to $2-3 \mathrm{~mm}$ long, entire or subentire on the margin; blades typically $10-30 \mathrm{~cm}$ long, $1.5-6 \mathrm{~cm}$ wide, base cuneate, glabrous on both sides; the constricted stalk-like part of the base ('petiole') 3.5-5 mm long. Flowering iterauctant, producing pseudospikelets as the basic unit of the inflorescence. Pseudospikelets 5-10 $\mathrm{mm}$ long, in clusters of few to many (more than 10), each composed of 0-2 small empty bracts at the base, followed by 1 or 2 bracts subtending prophyllated buds, 1 or 2 transitional (empty) glumes, 4-9 hermaphrodite flowers, and a terminal vestigial flower consisting only of a lemma and palea; rachilla internodes mostly about $1 \mathrm{~mm}$ long and $1 \mathrm{~mm}$ wide, strongly compressed, glabrous, disarticulating below the lemmas. Glumes not distinct from lemmas. Lemma 3-4 mm long, 7-9-veined, apex short-pointed, glabrous on the back, with scattered short flexuous appressed pale hairs on the inner (ventral) side and at the tip, minutely ciliate on the edges. Palea 3.5-4.5 $\mathrm{mm}$ long, distinctly protruding from behind the lemma in the mature pseudospikelet, 2-keeled, the keels bearing pale bristles $0.2-0.3 \mathrm{~mm}$ long, the back on the outer (dorsal) side with scattered minute pale hairs, on the inner (ventral) side with dense, flexuous, pale appressed hairs $0.1-0.2 \mathrm{~mm}$ long, the wings glabrous; indistinctly to 2-veined on the back, indistinctly to 2-veined on each wing. Lodicules 3, the posterior one larger, $0.3-0.5 \mathrm{~mm}$ long, somewhat oblong, pale ciliate on the margin, the two anterior ones smaller, 0.1-0.2 $\mathrm{mm}$ long, linear with laciniate margin. Stamens consistently 4; anthers narrowly sagittate, 2-2.5 mm long, the apical connective conspicuous, acute and spinulose on the surface; filaments fused into a short tube that elongates and becomes membranous as the flower matures, encasing the gynoecium within (the vascular traces always 6 at the very base of the filament tube). Ovary narrowly ovoid to cylindric, c. $0.1 \mathrm{~mm}$ long, glabrous, apex not conspicuously thickened; style to $3.5-4.5 \mathrm{~mm}$ long, slender, short-hairy distally; stigmas 1 or 2, plumose. Fruit unknown.

Notes -1 . The culm habit is truly fascinating. Bailey (1889) described it as "A rampant, climbing plant scaling the tops of the highest trees of the scrubs, and hanging in festoons from the branches, probably the stems extending 200 or more feet in 


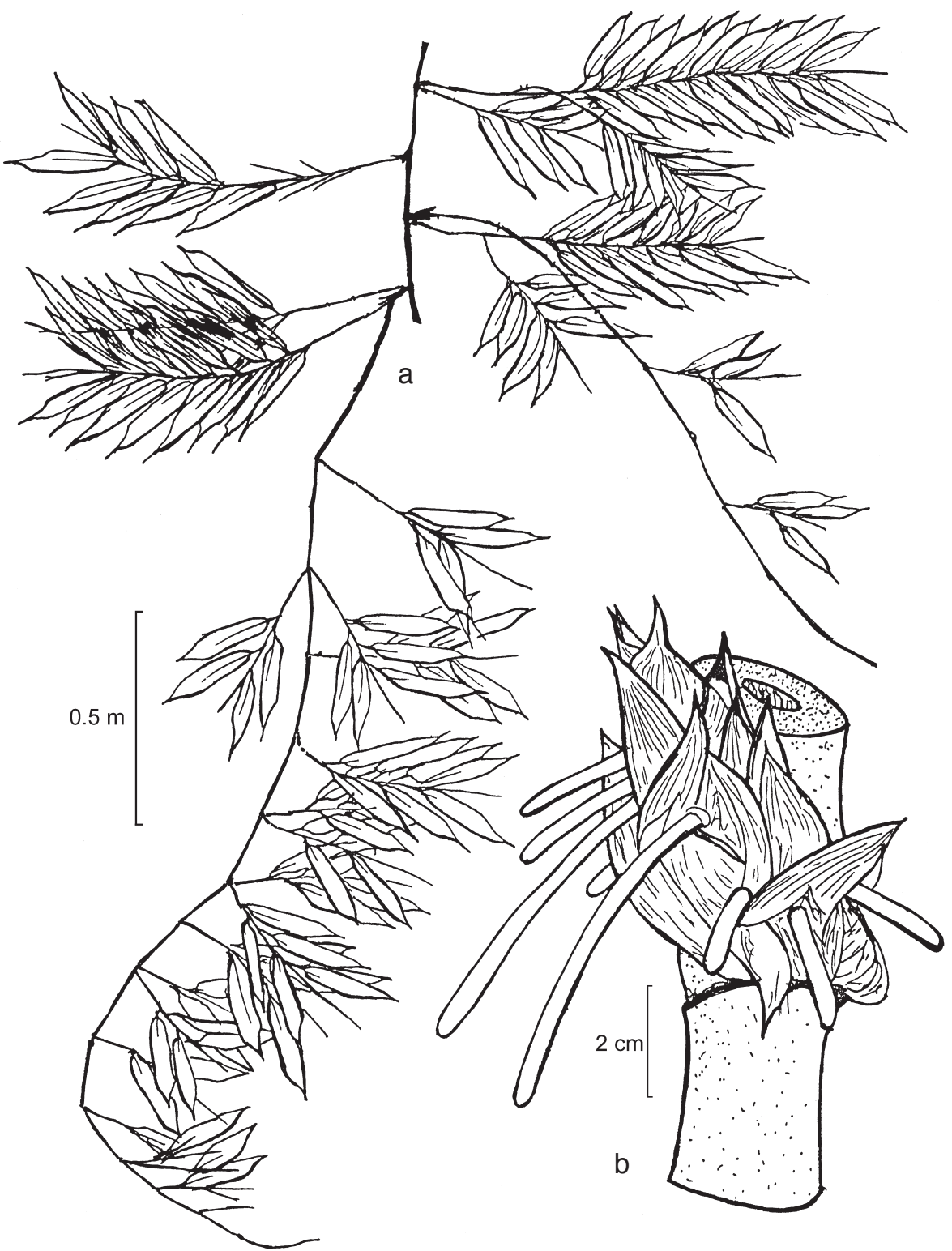

Fig. 7. Branching in the culm system of Mullerochloa moreheadiana (F.M. Bailey) K.M. Wong. a. Distal end of a culm system with clusters of leafy branches produced at normal branching nodes and a long branch developing reiteratively in the same way as the previous culm portion bearing it; b. a primary branch bud at a culm node beginning to develop a rhizome-like axis with short internodes, overlapping sheaths and roots (drawing by Len Muller based on Muller s.n. (KLU)). 
length ...". Many long 'culm sequences' result from the development of branches at various nodes along the original or main culm, which grow to comparable length and size as the main culm (Fig. 3). These branches are reiterative of the main culm in both dimension and behaviour (in the sense of Hallé et al., 1978 and Wong, 1986), and in turn produce the next series of such branches (Fig. 7). In time, such series of successively higher-order branching contribute to a plant body that is represented by long culms and culm-like higher-order branches, forming unwieldy tangles with the surrounding vegetation and, where they fall down, over the forest floor. Not infrequently, especially along lengths of culm suspended near to or lying on the forest floor, the main branch bud (and occasionally branches of this) at various nodes develops as a series of abbreviated internodes with loosely overlapping sheaths and conspicuous root development, effectively the slender 'neck' portions of new rhizome units (Fig. 4). These structures typically do not bear any buds at their nodes, except one or two buds at the very proximal nodes, which presumably have the potential to produce either culm-like or rhizome-like branches of the next order (Len Muller, pers. comm.; Fig. 8). This is similar to the situation in some Dinochloa spp., where recumbent lengths of culm also frequently develop such new rhizome units from branch buds along the culm (Wong, 1986). If such a rhizome unit touches the ground under favourable conditions, it may take root and develop a culm at its apex, and establish a clump through sympodial production of new rhizomes, in much the same way as a primary clump would develop from seed (Fig. 9). This appears to be a common method of vegetative reproduction in M. moreheadiana. Eventually, a well-developed plant of $M$. moreheadiana will become a complex of numerous plants that may be linked together by its scrambling culms. It can be difficult or impossible in such a situation to determine the site of a clump from which an original plant of Mullerochloa grew. This is functionally comparable to, but different in terms of development from the amphipodial rhizome system of some bamboos where true monopodial rhizomes (with slender, subterranean, hollow axes and rooting at the nodes) give rise, at intervals, to rhizome units that begin to branch sympodially (or 'tiller', producing subfusiform, solid units that grow downwards or laterally at first, then upturning to produce culms, the buds on these producing further similar rhizome units).

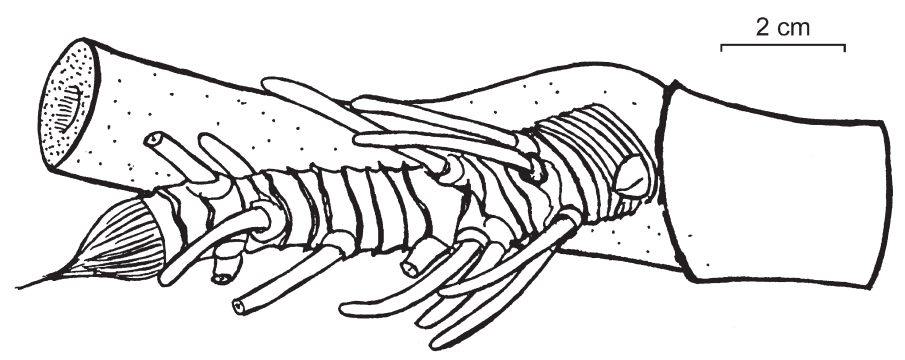

Fig. 8. Mullerochloa moreheadiana (F.M. Bailey) K.M. Wong. A rhizome-like extension developing from a primary branch bud with sheaths removed, revealing the origin of roots and a lack of secondary buds except at the very basal part; if this axis survives, it may upturn to form a new culm distally and more secondary buds may develop near the basal part of the culm, potentially forming further rhizome units (drawing by Len Muller based on Muller s.n. (KLU)). 


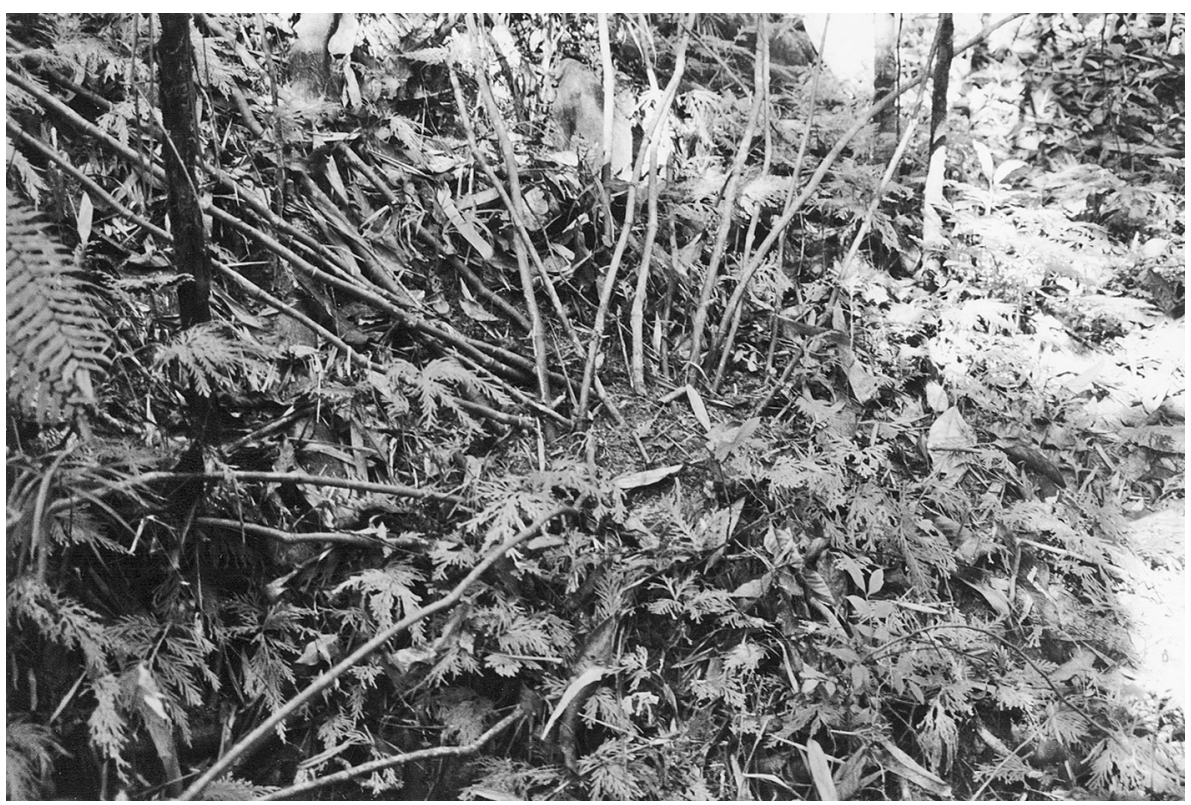

Fig. 9. A loose cluster of culms of Mullerochloa moreheadiana (F.M. Bailey) K.M. Wong, developing from a sympodial rhizome system (photo: Len Muller).

2. Clifford (1993) gives a review of the discovery and naming of this species in the 19 th century. The type material, collected by Bailey in 1888, represents vegetative parts only, without flowering material. Blake first collected flowering specimens in 1941, and this material was examined only much later by Clifford (1993). Further flowering material was collected by Kerns in 1956 and by Bruce Gray in 1986. From the range of material found in the Queensland Herbarium in Brisbane, the collections in the intervening years and afterwards are represented largely by vegetative material, indicating that flowering in this species is poorly known and infrequent, as also is the impression of Len Muller (pers. comm.), a keen observer of bamboos in Queensland, and Bruce Gray (pers. comm.), who made one of the few flowering collections of this bamboo.

Specimens examined:

AUSTRALIA. Queensland: Blake 14412 (BRI), Cook District, between Innisfail and East Palmerston, Nov. 1941, leafy and flowering branches; L. Muller s.n. (KLU), Innisfail, Mt Mirinjo Farm, Woopen Creek, 17-20 Dec. 2004, culm, rhizomes and leafy branches only; Blake 14972 (K), Deeral, near Babinda, 13 July 1943, culm and leafy branches only; Kerns s.n. (AD, BRI, CANB, K, L, MEL, MO, US), Bartle Frere township, Oct. 1956, leafy flowering branches only; Bailey s.n. (holotype BRI; isotype K), Russell River, Harvey's Creek, July-Aug. 1888, culm, leaves and culm shoot; Bailey s.n. (BRI, K), Dec. 1891, culm and leafy branch; Gray 4336 (BRI, QRS), 20232 RFV (BRI, QRS), State Forest Reserve 755, Badgery Logging Area, 19 Sept. 1986, leafy flowering branches; Williams 80139 (BRI), Cooper Creek, Cape Tribulation Road, 20 July 1980, leafy branches only; Moriarty 336 (BRI), Eubenangee via Innisfail, June 1970, culms and leafy branches only; Bean 3800 (BRI), Warraker Creek Road, NW of Innisfail, 23 Nov. 1991, leafy branch only. 


\section{ACKNOWLEDGEMENTS}

I am grateful to the Keeper, Royal Botanic Gardens, Kew (K), for the loan of specimens. Dr Laurie Jessep of the Queensland Herbarium at Brisbane (BRI), kindly gave permission for specimens to be photographed by Susan Jalaluddin of the Herbarium, University of Malaya (KLU). An anonymous reviewer provided helpful comment. Pung Vui Lee of the Forest Research Centre in Sandakan (SAN), Sabah, very kindly assisted with the documentation of specimens. Len Muller, Mt Mirinjo Farm, Innisfail, sent specimens for study, provided much information on the distribution and habit of the climbing bamboo and also kindly allowed the use of his illustrations for this work. Y.W. Low and M.S. Zahid kindly assisted with preparation of illustrations used.

\section{REFERENCES}

Bailey, F.M. 1889. Botany of the Bellenden Ker Expedition. Notes and Proceedings of the Legislative Assembly of Queensland Session 1889, 4: 26.

Bowman, D.M.J.S., B.A. Wilson \& C.R. Dunlop. 1988. Preliminary biogeographic analysis of the Northern Territory vascular flora. Austral. J. Bot. 36: 503-517.

Clifford, H.T. 1993. Bambusa moreheadiana F.M. Bailey (Magnoliophyta: Poaceae). Austrobaileya 4: $131-133$.

Dransfield, S. 1981. The genus Dinochloa (Gramineae-Bambusoideae) in Sabah. Kew Bull. 36: 613-633.

Dransfield, S. 1983. The genus Racemobambos (Gramineae-Bambusoideae). Kew Bull. 37: 661-679.

Dransfield, S. 1989. Sphaerobambos, a new genus of bamboo (Gramineae-Bambusoideae) from Malesia. Kew Bull. 44: 425-434.

Dransfield, S. 1996. New species of Dinochloa (Gramineae-Bambusoideae) in Malesia and notes on the genus. Kew Bull. 51: 103-117.

Dransfield, S. 1998. Cyrtochloa, a new genus of bamboo (Gramineae-Bambusoideae) from the Philippines. Kew Bull. 53: 857-873.

Dransfield, S. \& K. M. Wong. 1996. Temburongia, a new genus of bamboo (Gramineae: Bambusoideae) from Brunei. Sandakania 7: 49-58.

Franklin, D.C. 2003a. Morphology and taxonomy of the top end bamboo Bambusa arnhemica F. Muell., a little-known bamboo from northern Australia. Bamboo Science \& Culture, J. Amer. Bamboo Soc. 17: 44-54.

Franklin, D.C. 2003b. Bamboo and the northern Australian connection. Fl. Males. Bull. 13: $275-277$.

Hallé, F., R.A.A. Oldeman \& P.B. Tomlinson. 1978. Tropical trees and forests - an architectural analysis. Springer Verlag, Berlin.

Holttum, R.E. 1946. The classification of Malayan bamboos. J. Arnold Arbor. 27: 340-346.

Holttum, R.E. 1958. The bamboos of the Malay Peninsula. Gard. Bull. Singapore 16: 1-135.

Holttum, R.E. 1967. The bamboos of New Guinea. Kew Bull. 21: 263-292.

Liese, W. 1998. The anatomy of bamboo culms. Technical report No. 18. Int. Network for Bamboo and Rattan, Beijing.

Liese, W. \& D. Grosser. 2000. An expanded typology for the vascular bundles of bamboo culms. In: L. Puangchit, B. Thaiutsa \& S. Thamincha (eds.), BAMBOO 2000, Proceedings of the International Symposium, 2-4 August 2000, Chiangmai, Thailand. Royal Project Foundation, Kasetsart University, Bangkok.

McClure, F. A. 1934. The inflorescence in Schizostachyum Nees. J. Wash. Acad. Sci. 24: 541-548.

McClure, F.A. 1966. The bamboos: A fresh perspective. Harvard Univ. Press, Cambridge, Massachusetts.

Morley, R.J. 2003. Interplate dispersal paths for megathermal angiosperms. Persp. Pl. Ecol., Evol. \& Syst. 6: 5-20.

Muller, L. 1997. Three bamboo passengers on Gondwanan raft 'Australis'. Amer. Bamboo Soc. Newsl. 18, 2: 4-10. 
Soenarko, S. 1977. A new species of Nastus Nees (Gramineae) from Sumba. Gard. Bull. Singapore 30: 17-19.

Widjaja, E.A. 1997. New taxa in Indonesian bamboos. Reinwardtia 11: 57-152.

Wong, K.M. 1981. On the bamboo Racemobambos setifera. Malaysian Forester 44: 552-556.

Wong, K.M. 1986. The growth habits of Malayan bamboos. Kew Bull. 41: 703-720.

Wong, K.M. 1991. Schizostachyum terminale Holtt., an interesting new bamboo record for Borneo. Gard. Bull. Singapore 43: 39-42.

Wong, K. M. 1993a. Four new genera of bamboos (Gramineae: Bambusoideae) from Malesia. Kew Bull. 48: 517-532.

Wong, K.M. 1993b. A revision of Bambusa (Gramineae: Bambusoideae) in the Malay Peninsula, with two new species. Sandakania 3: 17-41.

Wong, K.M. 1995a. The morphology, anatomy, biology and classification of Peninsular Malaysian Bamboos. University of Malaya Botanical Monographs No. 1. University of Malaya, Kuala Lumpur.

Wong, K.M. 1995b. The bamboos of Peninsular Malaysia. Malayan Forest Records, No. 41. Forest Research Institute Malaysia, Kuala Lumpur. 